\title{
The Increased Ability in Constructing Sentence in Simple Present Tense with Picture Word Inductive Model
}

\author{
Melisa E. Salauwe ${ }^{1}$, I Nyoman Suparwa², Ni Luh Nyoman Seri Malini ${ }^{3 *}$ \\ elitamangindaan@gmail.com \\ Universitas Udayana, Denpasar 80114, Indonesia
}

\begin{abstract}
This research aimed to describe and analyze students' proficiency in constructing sentence in simple present tense before and after applying the PWIM, and the influencing factors that affects students' proficiency. The sample of this research is the 24 students of class 8B in Frater Don Bosco Junior High School Tomohon. This is an experimental type of research with qualitative and quantitative approach. A quasi-experimental, pretest and posttest one-group design is used in this research. The main theory used in this research is the theory of picture word inductive model. The data are gathered through observation, questionnaire, and test. A qualitative and quantitative method applied in analyzing the data. Meanwhile the other supported theory used are second language learning theory and grammatical theory. Based on the paired sample t-test conducted, it is known that the PWIM is significantly affect the students' proficiency in constructing sentence in simple present tense.
\end{abstract}

Published by IJRP.ORG. Selection and/or peer-review under responsibility of International Journal of Research Publications (IJRP.ORG)

Keywords: learning method; picture word inductive model; simple present tense

\section{Introduction}

Proficient in foreign language has become a demand in this globalization period. As challenging as it may be, the level of difficulty in learning foreign languages are different. This is due to the difference in systematic structure between the learners' mother language and the target language. This systematic difference tends to become an obstacle especially to young learners. Professor Li-Ling Chen, 2006 stated that learning foreign language is a complex process because learners are basically affected by his/her mother tongue. English has become one of the most important foreign languages in the educational world due to its popularity and being an international standard in terms of communications between nations. In Indonesia, English has become the first foreign language that must be learned from junior high school to college degree.

English learning in junior high school includes the four abilities in learning a language which are reading, listening, speaking, and writing. Schmidt, 2002 stated that writing is a reflection of interpersonal and intrapersonal supported by linguistic intelligence. This makes writing skills becomes much harder to learn and 
considered to be the highest-level ability compared to the other three. Therefore, before students learn how to write they need to learn the systematic structure (grammar). It is not uncommon that after a student only learns how to write, they are still unable to produce a proper writing both in terms of content and language structure. The ability they have is only limited to a simple theory of writing. In other words, grammar has become a purpose that a language learners' need to achieve in order to be a good language speaker and a writer (DeCapua, 2008).

Grammar took the form of structural rules in language when it comes to constructing a sentence, phrase, and even word. One of the challenges in learning grammar is tenses. Tenses is a systematic time in English that function to refer to the past, present, and future. According to Kridalaksana, 2008, time in linguistic means a distinguish of verbs to state a difference in time of act or situation. One of the tenses types is simple present tense. Sentence with simple present tense pattern is quite simple and often becomes the basic of the other sentences. This type of sentence can be described as a sentence that none of its function placed with a clause. In other words, simple present sentence only consists of one independent clause that grammatically fulfill the condition to stand on its own. Simple present tense usually states a face, habitual activity, or an event happen continuously.

Based on the observation conducted at Frater Don Bosco Junior High School, a complex problem of students understanding towards simple present tense is shown. The daily exam results of class $8 \mathrm{~B}$ has come to attention where $13(54.16 \%)$ out of 24 students have not yet successfully pass the test. One of the problem that surfaced in the students' English learning is their lack of proficiency in English grammar. Majority of students may be able to verbally utter the grammar rules however they hardly able to reflect this in a proper example. When it comes to simple present tense, class $8 \mathrm{~B}$ has the lowest score compared to the other classes. The errors occurred when they are unable to figure out the subject-verb agreement as well as the usage of adverb. The students also have not reached the ability to properly use auxiliaries (is, am, do or does).

To develop a more interesting learning process for students, a teacher needs to find an alternative way. One among many ways is to utilise the attractive aspects of images. In 1998, Emily F. Calhoun developed a learning method that able to stimulate students vocabulary. The goal is so the word may be easily expand to a sentence. This method is known as picture word inductive model (PWIM). Calhoun expressed that through PWIM, students are attracted to explore a picture and to get introduced to new words using their natural ability in read and write and to think inductively. In PWIM, students will learn in a classical way, in groups or individually as long as they are able to be motivated and able to construct a proper sentence in simple present tense.

\section{Theoretical Framework}

\subsection{Theory of picture word inductive model}

Joyce and Calhoun, 1998 stated that PWIM is designed to become a big component in the arts of language curriculum, focussing towards beginner in the basic level and higher. This model coincidentally grouped along with the information processing model because its pedagogical focus are around the construction of various subjects whereas the students able to investigate deeper into language, in terms of form and usage such as how a letter, word, phrase, sentence or longer text function to support a communication in English. This model push the students to read, expand their vocabulary, develop their ability in both phonetic and structural analysis, as well as helping them understand how to make a good use of a wider amount of texts. Huda, 2013 stated four stages in PWIM learning which are the introduction of words, the identification of word, the review of words, and constructing words in a sentence. 


\subsection{Second language learning theory}

Second language is a language acquired after the first language is learned. Second language acquisition is a gradual range that begins from the proficiency of the first language (B1) with little knowledge of the second language (B2) and then the proficiency of the second language increased in time until it is as good as the first language. In the process of learning a second language which in this case English, making a mistake is inevitable (Dulay, 1982). Common mistakes occurred in the process of learning a second language is often caused by the first language. The grammatical errors that are commonly encountered by students in constructing simple present tense are as follow (Tarigan, 2011).

- Omission; errors caused because due to the absence of certain elements that supposed to exist within a particular language unit. A word in a sentence is a potential candidate of omission, however some types of words are more often omitted compared to the others. In fact, grammatical morpheme such as preposition, conjunction, to be, and an article often omitted from content word especially in a daily conversation.

- Double marking; is one of the types of addition errors. This error is the presence of an element that are not supposed to exist in a proper speech. Double marking caused by addition, failed to omit or avoid some element needed in a certain linguistic construction but are not necessary to be omitted in other construction. In English, this type of error can be seen in the mark of time or tense.

- Misformation; errors marked by the usage of word form or wrong structure. In an omission, this element does not exist at all therefore in misformation, students prepare or give something, even if it does not exist at all. Form errors or misformation are also divided in three types which are regulation, archi-forms, and alternating forms.

- Misordering; this type of errors is caused by the placement or sorting a certain element in an inappropriate order. Errors in misordering can be seen in the disorder of word or group of words.

\subsection{Grammatical theory}

Language is series of signals, rules, structure and pattern, formed in a complete unit. Grammar is a rule in constructing and combining words to sentence (Hornby, 1989). Grammar has become a landmark in learning a language due to all aspects within a sentence. With these in mind, learning a simple present tense in English are focussing on the language characteristic of that tense. The pattern of simple present tense are as follow.

- Positive sentence: $\mathrm{S}+\mathrm{V} 1+\mathrm{O}$, or for third person singular $\mathrm{S}+\mathrm{V} 1$ (s/es) $+\mathrm{O}$.

- Negative sentence: $\mathrm{S}+$ do not $+\mathrm{V} 1+\mathrm{O}$, or for third person singular $\mathrm{S}+$ does not $+\mathrm{V} 1+\mathrm{O}$.

- Interrogative sentence: do $+\mathrm{S}+\mathrm{V} 1+\mathrm{O}$, or for third person singular does $+\mathrm{S}+\mathrm{V} 1+\mathrm{O}$.

\section{Method}

Experimental method is applied in this research with quantitative and qualitative approach. In instance, a quantitative descriptive method is applied to analyse the pretest and posttest results of constructing sentences in simple present tense. At the same time, a qualitative descriptive method is applied in order to give a clear image and to describe the analysis results regarding the students' ability to construct sentences in simple present tense, before and after applying the PWIM. A quasi-experimental design is used in this research with pretest and posttest one-group design. This research is conducted two times as in before the experiment and after the experiment of one sample. 


\section{Result and Discussion}

\subsection{Students' proficiency before applying the PWIM}

Pretest is conducted before applying the PWIM in order to extract data or an initial description of students' proficiency in constructing sentence in simple present tense. On top of that, it may also able to scale the students' achievement in class. The students' results were analyzed using Brown's assessment criteria where the aspects considered are the structures, spelling, word choice and proper writing. Based on the pretest scores, it is known that the class' average results is 68.98 where the student with highest score achieve 82.13 and 48 as the lowest. From this result, 15 students $(62.5 \%)$ have not yet reached the standard completeness score which is $\geq 75$ while only 9 students (37.5\%) achieved this minimum standard. In other words, this may be interpreted that the students' proficiency in constructing simple present sentence is considerably low and needs to be improved.

\subsection{Students proficiency after applying the PWIM}

The posttest is given after applying the PWIM to extract data or final description of students' proficiency in constructing sentence in simple present tense. The form of posttest is similar to the pretest in hope of a more accurate and significant result. As analyzed on the pretest, the posttest assessment criteria referred to Brown where structures, spelling, word choice, and proper writing are considered. The posttest result shown the class' average score which are 87.47. This result is much higher compared to the average score achieved on the pretest which is 69.98. This difference shown a significant increase of students' proficiency by 18.49. The highest score achieved during the posttest is 98.4 while the lowest reached 68. In instance, 21 students $(87.5 \%)$ reached the standard completeness score which is $\geq 75$ and only 3 students $(12.5 \%)$ who have not. In other words, the percentage of students' achievement score based on minimum completeness criteria is $87.5 \%$ from the total samples.

Although we can see a definite increase in their score, a proper calculation is required in order to prove that this is due to PWIM being applied. Therefore, a statistic analysis using IBM SPSS Software for MacOS is utilised to elaborate the calculation. The results shown that the $t_{\text {count }}$ is as much as 13.326 , therefore the value of $t_{\text {count }}$ is $13.326>2.068$ ( $t_{\text {table }}$ ). This comparison shows that there is a definite influence of PWIM towards students' proficiency.

\subsection{The influencing factors that affect students' proficiency}

Based on the questionnaire result, the students gave positive response of the applying of PWIM in the learning process. Apart from that, their answers in the questionnaires also contributes to the influencing factors that affects the increase of proficiency in conducting sentence in simple present tense. These factors are students' interest, students' cognitive comprehension, classroom environment, learning method, and student's motivation.

\section{Conclusion}

1. The pretest shown only 9 students or $37.5 \%$ that achieve the standard completeness standard given by the school which is $\leq 75$, while 15 students or $62.5 \%$ have not reached it. The class' average score of 68.98 is also quite low. This is caused due to their errors in constructing sentence in simple present tense. The errors found are including writing assessment aspects in constructing a proper sentence 
which are structure, subject-verb agreement, word use, spelling, and the usage of upper case as well as punctuation mark.

2. The students' proficiency in constructing sentence in simple present tense after applying the PWIM had an increase. 21 students or $87.5 \%$ achieve the standard completeness score which is $\leq 75$, while only 3 students or $12.5 \%$ have not reached it. The average class' score is 87.47 which categorized as good. This increased are still within the scope of constructing sentence in simple present tense where the students follow the learning procedure hence minimizing their original errors in the five assessment aspect in writing sentence. Based on the paired sample $t$-test, the $t_{\text {count }}$ is 13.326 which is greater than the $t_{\text {table, }}$ it is 2.068. This concludes that the PWIM had an influence towards the students' learning result.

3. The influencing factors that affects the students' learning results through PWIM are students' interest, students' cognitive comprehension, classroom environment, learning method, and student's motivation.

\section{References}

Calhoun, E., 1999. Teaching Beginning Reading and Writing with the Picture Word Inductive Model, Editor. Association for Supervision and Curriculum Development, Alexandria.

DeCapua, A., 2008. Frammar for Teachers: A Guide to American English for Native and Non-native Speakers, Editor. Springer Science $\&$ Business Media, LLC., New York.

Dulay, H., 1982, Language Two, Editor. Oxford University Press, Oxford, p. 139.

Hornby, A., S., 1989, Oxford Advanced Learners Dictionary, Editor. Oxford University Press, Oxford, p. 542.

Huda, M., 2015. Model-model Pengajaran dan Pembelajaran, Editor. Pustaka Pelajar, Yogyakarta, p. 86-87.

Joyce, B., Wiel, M., Calhoun, E., 2011. Models of Teaching, Eight Edition, Editor. Pearson Educations, Inc., New York.

Kridalaksana, H., 2008. Kamus Linguistik, Editor. Gramedia Pustaka Utama, Jakarta.

Richard, J.., and Richard, S., 2002. Longman Dictionary of Language teaching and Applied Linguistics, Third Edition, Editor. Pearson Education Ltd., London, p. 148.

Tarigan, H., G., 2011, Pengajaran Analisis Kesalahan Berbahasa, Editor. Angkasa, Bandung, p. 133-141. 